\title{
IMPACTS OF URBAN SOLID WASTE DISPOSAL ON THE QUALITY OF SURFACE WATER IN THREE CITIES OF MINAS GERAIS - BRAZIL
}

\author{
Impactos da disposição de resíduos sólidos urbanos na qualidade da água \\ superficial em três municípios de Minas Gerais - Brasil
}

\author{
Rosângela Francisca de Paula Vitor Marques' ${ }^{1}$, Antônio Marciano da Silva², \\ Luciano dos Santos Rodrigues ${ }^{3}$, Gilberto Coelho ${ }^{2}$
}

\begin{abstract}
The environmental impact of three different urban solid waste facilities (USWF) on the quality of the surface water. The studied areas were the Campo Belo sanitary landfill (Varões River), the controlled landfill of Santo Antônio do Amparo (Fabiano River), and the closed dump of Elói Mendes (Mutuca River), which are cities located in southern Minas Gerais state, Brazil were evaluated. At each sampling point water samples were collected at five occasions in the raining season (October - March) and in the dry season (April - June) at three sampling points: (P1) upstream the solid waste facility, $(\mathrm{P} 2)$ downstream nearby the point of influx from the sewage treatment plant in the sanitary landfill, or at the drainage point from the surface flow of the dump and controlled landfill, and (P3) downstream the solid waste facility. Physicochemical and bacteriological analyses were performed, and the results were analyzed based on descriptive statistics. The data were also compared with reference values from the National Environmental Council (CONAMA) Resolution 357/2005 and were used to calculate the water quality index (WQI). It was not possible to detect a significant effect of the solid waste facility on the water quality indicators. The water conditions were unsatisfactory due to violations of the concentrations of phosphorus, ammonia, fecal coliform, and the biochemical oxygen demand/chemical oxygen demand ratio (BOD/COD), probably related to other uses along the drainage area upstream the solid waste facility. These conditions were more critical in the Mutuca river, where the WQI was classified as bad during the entire period at all sampling points.
\end{abstract}

Index terms: Environmental contamination, water quality index, sanitary landfill, controlled landfill, dump.

\section{RESUMO}

Os impactos ambientais de três diferentes tipologias de áreas de disposição de Resíduos Sólidos Urbanos - ADRSU, sobre a qualidade das águas superficiais situadas nas proximidades do aterro sanitário de Campo Belo (Córrego dos Varões), do aterro controlado de Santo Antônio do Amparo (Córrego do Fabiano) e do lixão encerrado de Elói Mendes (Ribeirão Mutuca), municípios situados no Sul de Minas Gerais - Brasil foram avaliados. Para cada curso d'água foram coletadas 5 amostras de água no período chuvoso e 5 amostras no período seco, em três diferentes pontos para cada um dos três cursos d'água sendo: (P1) a montante das ADRSU, (P2) logo após o local de descarga da Estação de Tratamento de Esgoto - ETE (no aterro sanitário, e nas outras tipologias, após ponto de lançamento do escoamento superficial proveniente das ADSRU, e (P3) à jusante das ADSRU. Realizaram-se análises físico-químicas e bacteriológicas, cujos resultados foram analisados com base na estatística descritiva e comparados com valores de referência da Resolução CONAMA 357/2005, bem como utilizados para cálculo do índice de qualidade de água (IQA). Não foi possível detectar efeito significativo das ADRSU, nos parâmetros indicadores da qualidade da água, a qual se apresentou em condições não satisfatórias em função das violações dos parâmetros fósforo, amônia, coliformes termotolerantes e da relação DQO/DBO mesmo à montante da ADSRU. No Ribeirão Mutuca, essa situação foi ainda mais crítica pois o IQA foi classificado como ruim em todos os pontos durante o período monitorado.

Termos para indexação: Contaminação ambiental, índice de qualidade de água, aterro sanitário, aterro controlado, lixão.

(Received in may 23, 2012 and approved in october 31, 2012)

\section{INTRODUCTION}

The steady growth of urban populations and rapid increase in solid waste generation has emerged as one of the main pressing issues of human society, especially in developing countries (BRUNNER; BROWN, 1988; D'ALMEIDA; VILHENA, 2000; POKHREL;
VIRARAGHAVAN, 2005; MARKANDYA, 2006). Improper disposal of solid waste leads to contamination of soil, air, and surface and groundwater. This contamination alters physical, chemical, and biological characteristics of the environment and places human health at risk. Urbanization leads to spatial concentration of solid waste, what reduces

\footnotetext{
${ }^{1}$ Universidade Federal de Lavras/UFLA - Departamento de Engenharia/DEG - Cx. P. 3037 - 37200-000 - Lavras - MG - Brasil rosarecursoshidricos@posgrad.ufla.br

2Universidade Federal de Lavras/UFLA - Departamento de Engenharia/DEG - Lavras - MG - Brasi

${ }^{3}$ Universidade Federal de Minas Gerais/UFMG - Departamento de Medicina Veterinária Preventiva/DMVP - Belo Horizonte - MG - Brasil
}

Ciênc. agrotec., Lavras, v. 36, n. 6, p. 684-692, nov./dez., 2012 
the potential that environments have to assimilate contaminants. Environmental contamination resulting from solid waste can reach high levels and negatively affect people and the local fauna and flora (CASTILHOS JÚNIOR, 2006).

Leachate and gases are the major problems caused by garbage decomposition, although a series of other problems is also observed such as: a) pollution of soil, nearby surface waters, and ground waters; b) visual pollution; c) unpleasant odors; d) presence of animal scavengers; e) presence of people scavenging discarbe resources including children; f) increased occurrence of disease vectors, which directly impact the local and regional human; g) presence of gases with greenhouse and explosive effects, dioxins, and furans resulting from burning; h) intense landscape degradation; i) increase of fire hazard; and j) devaluation of local real estate (LANZA, 2009).

Landfill leachate is generated by excess rainwater percolating the waste layers. Physical, chemical, and microbial processes transfer pollutants from waste to percolating water (CHRISTENSEN; KJELDSEN, 1989). The effects of leachate on the quality of the surface and ground waters depend on the leachate's composition. However, the biodegradability of the organic content in the solid waste and the compaction of the waste layers make the landfill an anaerobic environment, conferring similarities to the leachate composition among different landfills (KJELDSEN et al., 2002). Leachate is by far the most significant threat to groundwater because it can reach the deepest layers of landfills (OLIVEIRA; PASQUAL, 2001). Through percolation, leachate carries soluble substances and may flow laterally to nearby areas, move upwords and reach the surface or move through the base of the landfill toward the subsurface (WALLS, 1975; ZANONI, 1972).

In Brazil, more than $300 \mathrm{~g}$ of waste per capita are generated daily from sweeping and cleaning streets and garbage (PEÑIDO; ZVEIBIL, 2001). The national average production urban solid waste $900 \mathrm{~g} / \mathrm{day} /$ person. However, this estimate depends on the size of the city and may reach $1,300 \mathrm{~g} /$ day/person in cities such as Rio de Janeiro and São Paulo. In 50.8\% of Brazilian cities, open-air dumps are still the final destination for solid waste (INSTITUTO BRASILEIRODE GEOGRAFIAE ESTATÍSTICA-IBGE, 2008). However, solid waste management has changed significantly in the last 20 years. The use of sanitary landfills, which is the most appropriate way to dispose of solid waste, has increased from $17.3 \%$ of cities in 2000 to $27.7 \%$ in 2008. In the state of Minas Gerais, the number of cities disposing waste in open-air dumps decreased significantly from $96 \%$ in 2001 to $37 \%$ in 2010 (FUNDAÇÃO
ESTADUAL DE MEIO AMBIENTE-FEAM, 2010). The law 12305/2010 of the National Policy on Solid Waste establishes policies for the integrated management of solid waste (including hazardous waste), defines responsibilities of those generating waste and of the public administration, and specifies applicable economic measures (BRASIL, 2010).

In general, there are 3 kinds of facilities for disposal of urban solid waste: a) dumps, or the simple deposition of waste on the soil without technical criteria or measures to protect the environment or public health; b) controlled landfill, a method preferable to a dump but features a level of quality considerably inferior to the sanitary landfill; and c) sanitary landfill, which is the most appropriate one (AZEVEDO et al., 2003). This disposal facility produces localized pollution because there is no impermeabilization of the base (compromising the soil and groundwater quality), no percolated liquid treating system (leachate plus infiltrated water), or extracting and controlling the burning of the gases generated.

Intensification of industrialization, urbanization, agricultural activities, and population growth have resulted in increased demand for water as well as in an increased flow of contaminants into water bodies, (HOLT, 2000; PINTO, 2009). Urban activities have a direct influence on water quality within hydrographic basins because effluents flow into waterways in many cases without passing through any treatment process. The most significant contamination routes are those related to direct and indirect emissions of treated and untreated sewage, runoff, atmospheric deposition, and pollution. The quality of surface water has become a critical issue in many countries, especially due to concern about the scarcity of water, requiring a program for monitoring the surface and groundwater to protect this resource (PESCE; WUNDERLIN 2000). Various water monitoring technologies are necessary to monitor the quality of the local water. In this context, the objective of this study was to evaluate the environmental impact of three different types of urban solid waste facilities-dump, controlled landfill, and sanitary landfill, on quality of surface waters under field conditions.

\section{MATERIAL AND METHODS}

The characteristics of the cities and identification of the USWF are summarized in table 1 and description of the rivers in table 2 and figure 1 . The methods for surface water sample collection, preservation, and parameters analyses followed the standard methods for the examination of water and wastewater (APHA, 1998). 
Table 1 - Characteristics of the studied cities and their waste disposal plants.

\begin{tabular}{ccccccc}
\hline City & $\begin{array}{c}\text { Geographic } \\
\text { coordinates }\end{array}$ & $\begin{array}{c}\text { Area } \\
\text { (ha) }\end{array}$ & $\begin{array}{c}\text { Human } \\
\text { population }\end{array}$ & $\begin{array}{c}\text { Solid waste } \\
\text { production (tons/day) }\end{array}$ & $\begin{array}{c}\text { Solid waste } \\
\text { disposal method }\end{array}$ & $\begin{array}{c}\text { Adjacent } \\
\text { river }\end{array}$ \\
\hline Elói Mendes & $\begin{array}{l}21^{\circ} 37^{\prime} 55^{\prime \prime} \mathrm{S} \\
45^{\circ} 34^{\prime} 211^{\prime \prime} \mathrm{W}\end{array}$ & 2.5 & 21,907 & 12.5 & dump & Mutuca \\
$\begin{array}{c}\text { Santo Antônio } \\
\text { do Amparo }\end{array}$ & $\begin{array}{l}20^{\circ} 58^{\prime} 34^{\prime \prime} \mathrm{S} \\
44^{\circ} 56^{\prime} 45^{\prime \prime} \mathrm{W}\end{array}$ & 3.0 & 17,255 & 9.0 & $\begin{array}{c}\text { controlled } \\
\text { landfill } \\
\text { sanitary } \\
\text { landfill* }\end{array}$ & Fabiano \\
Campo Belo & $\begin{array}{l}20^{\circ} 51^{\prime} 47^{\prime} \mathrm{S} \\
45^{\circ} 17^{\prime} 455^{\prime \prime} \mathrm{W}\end{array}$ & 10.5 & 51,544 & 30.0 & Varões \\
\hline
\end{tabular}

* In an adjacent area there is a dump that has been closed.

Table 2 - Characteristics of rivers under the influence of the studied waste disposal plants.

\begin{tabular}{|c|c|c|c|c|c|c|}
\hline \multirow[t]{2}{*}{ River } & \multirow{2}{*}{$\begin{array}{l}\text { Main drainage } \\
\text { uses }\end{array}$} & \multirow{2}{*}{$\begin{array}{l}\text { Drainage } \\
\text { area }\left(\mathrm{km}^{2}\right)\end{array}$} & \multirow{2}{*}{$\begin{array}{c}\text { Average } \\
\text { declivity }(\%)\end{array}$} & \multirow{2}{*}{$\begin{array}{l}\text { Average flow } \\
\qquad\left(\mathrm{m}^{3} / \mathrm{s}\right)\end{array}$} & \multicolumn{2}{|c|}{$\begin{array}{c}\text { Geographic coordinates } \\
\text { of sampling points }\end{array}$} \\
\hline & & & & & upstream & downstream \\
\hline Mutuca & $\begin{array}{l}\text { coffee growing, } \\
\text { livestock }\end{array}$ & 7.95 & 2.0 & $\begin{array}{l}0.093 \\
0.341\end{array}$ & $\begin{array}{l}21^{\circ} 38^{\prime} 15.8^{\prime \prime} \mathrm{S} \\
45^{\circ} 34^{\prime} 26.9 ” \mathrm{~W}\end{array}$ & $\begin{array}{l}21^{\circ} 38^{\prime} 0.2^{\prime \prime} \mathrm{S} \\
45^{\circ} 34^{\prime} 10.5^{\prime \prime} \mathrm{W}\end{array}$ \\
\hline Fabiano & pasture, livestock & 2.31 & 1.9 & 0.072 & $\begin{array}{l}20^{\circ} 58^{\prime} 40.4^{\prime \prime} \mathrm{S} \\
44^{\circ} 56^{\prime} 30.7^{\prime \prime} \mathrm{W}\end{array}$ & $\begin{array}{l}20^{\circ} 58^{\prime} 18.8^{\prime \prime} \mathrm{S} \\
44^{\circ} 56^{\prime} 37.2^{\prime \prime} \mathrm{W}\end{array}$ \\
\hline Varões & corn growing & 0.90 & 4.4 & 0.016 & $\begin{array}{l}20^{\circ} 51^{\prime} 49.7 ” \mathrm{~S} \\
45^{\circ} 17^{\prime} 56.7^{\prime \prime} \mathrm{W}\end{array}$ & $\begin{array}{l}20^{\circ} 51^{\prime} 51.3 ” \mathrm{~S} \\
45^{\circ} 17^{\prime} 53.8^{\prime \prime} \mathrm{W}\end{array}$ \\
\hline
\end{tabular}

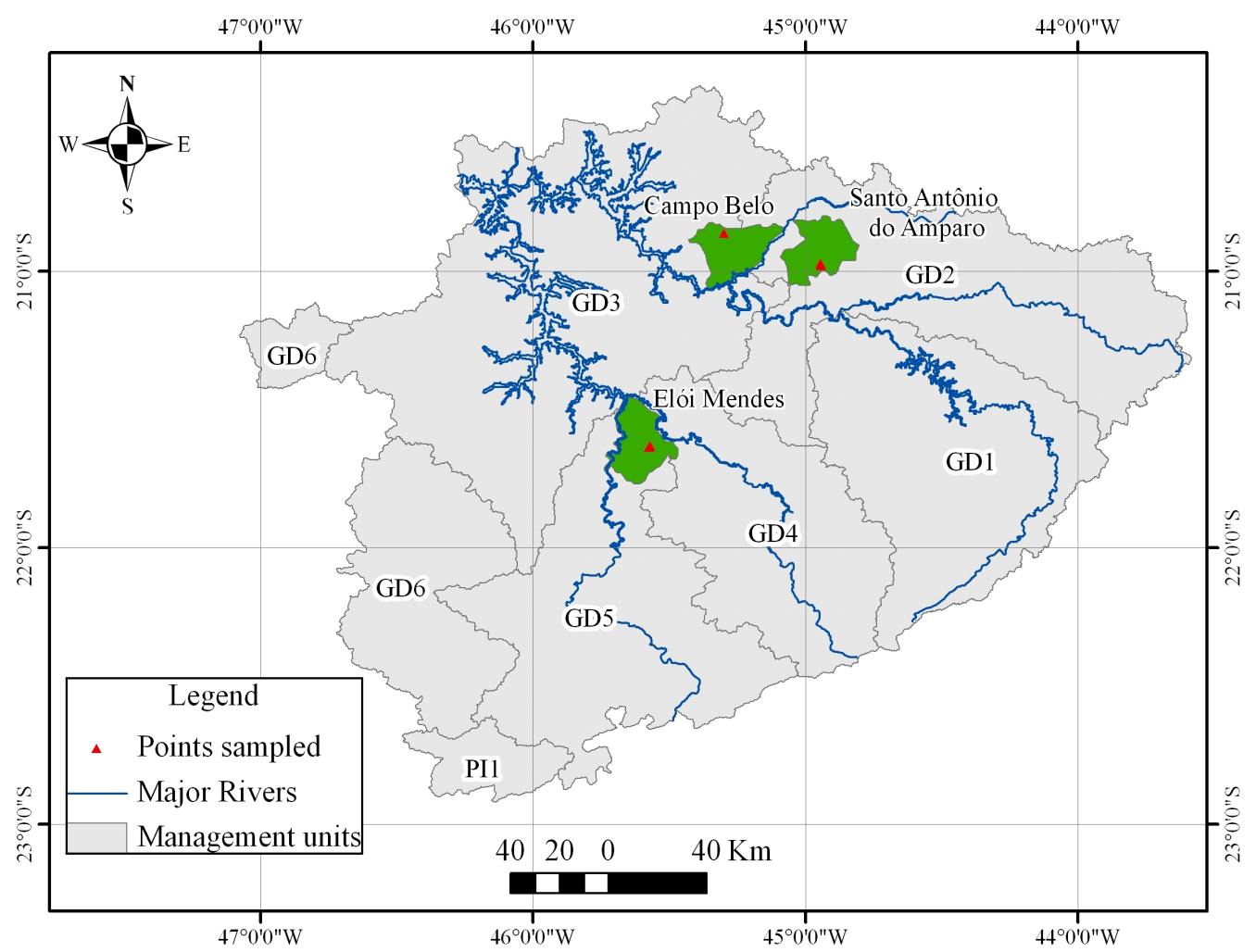

Figure 1 - Location of the sampling points within the studied drainages in the Rio Grande basin, south Minas Gerais, Brazil.

Ciênc. agrotec., Lavras, v. 36, n. 6, p. 684-692, nov./dez., 2012 
Water samples were collected using 2-L flasks; samples collected for bacteriological tests were collected in sterilized flasks. All samples were stored at $4^{\circ} \mathrm{C}$. Samples were collected at three sampling points along each of the three studied rivers: (P1) upstream the solid waste facility; (P2) downstream nearby the point of influx from the sewage treatment plant in the sanitary landfill, or at the drainage point of surface flow of the dump and controlled landfill; and (P3) downstream the solid waste facility. At each sampling point water samples were collected at five occasions in the raining season (October - March) and in the dry season (April - June). The water parameters measured were: air temperature, water temperature, $\mathrm{pH}$, turbidity, electric conductivity, dissolved solids (DS), dissolved oxygen (DO), biochemical oxygen demand (BOD), chemical oxygen demand (COD), color, chlorides, total solids (TS), fixed solids (FS), volatile solids (VS), total suspended solids (TSS), and total and fecal coliforms. The samples were analyzed in the Laboratory of Water Analyses, Department of Engineering, Federal University of Lavras. The levels of nitrate, total phosphorus, and ammonia nitrogen were analyzed in the Laboratory of Environmental Sanitation, Veterinary School, Federal University of Minas Gerais. River flow rate measurements were taken in situ by the floater method at each sampling occasion. In the Mutuca river, flow measurements were taken both upstream and downstream the point of convergence of an affluent creek.

Descriptive statistics of the water physical, chemical, and bacteriological parameters, were compared with reference values for Class II, indicating potability level of freshwater, of the Resolution 357/2005 of the National Environmental Council (CONSELHO NACIONALDE MEIO AMBIENTE, 2005). Averages were compared using the $t$-test with a $95 \%$ significance level $(\mathrm{p}<0.05)$ for each parameter monitored. Another evaluation was based on the Water Quality Index (WQI) proposed by the Water Management Institute of Minas Gerais state (INSTITUTO MINEIRO DE GESTÃO DAS ÁGUASIGAM, 2004).

\section{RESULTS AND DISCUSSION}

\section{Water quality parameters}

The factor for the position of the sampling point for surface water for the three rivers (Mutuca, Varões, and Fabiano) did not show significant differences for any of the parameters (statistical $t$-test). Analysis of descriptive statistics identified that some water parameters were above the reference values from CONAMA Resolution 357/2005 (Table 3).

Table 3 - Descriptive statistics for water quality indicators in the tree sampling points in the studied rivers.

\begin{tabular}{|c|c|c|c|c|c|c|c|c|}
\hline & \multirow{2}{*}{ Water parameters $(\mathrm{mg} / \mathrm{L})$} & \multicolumn{2}{|c|}{ Mutuca River } & \multicolumn{2}{|c|}{ Varões River } & \multicolumn{2}{|c|}{ Fabiano River } & \multirow{2}{*}{$\begin{array}{l}\text { Reference } \\
\text { values** }\end{array}$} \\
\hline & & Average & $\mathrm{CV}(\%)$ & Average & $\mathrm{CV}(\%)$ & Average & $\mathrm{CV}(\%)$ & \\
\hline \multirow{5}{*}{ P1 } & BOD & 0.92 & 46.74 & 2.03 & 92.61 & 0.66 & 124.24 & 5.00 \\
\hline & $\mathrm{FC} * * *$ & $1.04 \times 10^{4 *}$ & 0.30 & $63.8^{*}$ & 366.62 & $66.5^{*}$ & 171.38 & $1 \times 10^{3}$ \\
\hline & Ammonia & 5.42 & 64.02 & 4.76 & 78.36 & 7.05 & 39.72 & - \\
\hline & Phosphorus & 2.83 & 76.33 & 1.42 & 128.17 & 1.48 & 120.95 & 0.05 \\
\hline & $\mathrm{COD} / \mathrm{BOD}$ & 21.67 & & 7.63 & & 12.85 & & \\
\hline \multirow{5}{*}{$\mathrm{P} 2$} & BOD & 1.10 & 77.27 & 1.94 & 87.11 & 0.81 & 88.89 & 5.00 \\
\hline & $\mathrm{FC} * * *$ & $2.96 \times 10^{4 *}$ & 0.01 & $1.21 \times 10^{3 *}$ & 15.55 & $205^{*}$ & 150.33 & $1 \times 10^{3}$ \\
\hline & Ammonia & 7.05 & 39.72 & 4.87 & 45.38 & 7.69 & 36.80 & - \\
\hline & Phosphorus & 1.82 & 34.62 & 1.11 & 32.43 & 0.57 & 73.68 & 0.05 \\
\hline & COD/BOD & 12.78 & & 8.32 & & 6.7 & & \\
\hline \multirow{5}{*}{ P3 } & BOD & 1.16 & 72.41 & 2.29 & 63.76 & 1.19 & 92.44 & 5.00 \\
\hline & $\mathrm{FC} * * *$ & $2.69 \times 10^{3 *}$ & 2.60 & $420^{*}$ & 57.83 & $1.49 \times 10^{3 *}$ & 12.93 & $1 \times 10^{3}$ \\
\hline & Ammonia & 7.60 & 41.84 & 4.90 & 46.12 & 7.76 & 27.71 & - \\
\hline & Phosphorus & 2.10 & 38.10 & 0.94 & 18.09 & 0.59 & 83.05 & 0.05 \\
\hline & COD/BOD & 10.07 & & 8.34 & & 19.81 & & \\
\hline
\end{tabular}

* Geometric average. ** Reference values from CONAMA Resolution 357/2005; Values in bold are greater than the reference value. $* * *(\mathrm{NMP} / 100 \mathrm{~mL})$. 
Phosphorus levels in all 3 sampling points of the three rivers were higher than the reference value $(0.05 \mathrm{mg} /$ L), what may lead to eutrophication of these rivers. Phosphorus may originate from natural dissolution of soil compounds and organic matter decomposition as well as from anthropogenic activities, such as domestic effluents, animal excrement, and fertilizers. Excess phosphorous in the studied rivers may be related to agricultural activities, which are the main uses of these drainages upstream from the USWF (Table 2).

Ammonia levels also were above the average reference value of $3.7 \mathrm{mg} / \mathrm{L}$ for $\mathrm{pH}<7.5$. Occurrence of ammonia in waterways usually results from the conversion of organic nitrogen originated from animal excrement and fertilizers. Ammonia in its free form is highly toxic to fish (VON, 2005). The coefficients of variation for ammonia averages were relatively low, suggesting that the pollution level was stable for the whole period, or that variations in water flow compensated variations in the pollution level.

Another indicator for which the values were over the maximum allowed by the CONAMA Resolution 357/ 2005 is the thermotolerant fecal coliform group. In the Fabiano River, there was a violation at the point downstream from the solid waste facility. This contamination was likely related livestock raising activities in adjacent areas, which negatively impacts water quality (MERTEN; MINELLA, 2002). In the Varões River, a violation occurred at P2 (where the treated effluent from the sewage treatment plant of the sanitary landfill flows into the river) as well as due to the surface drainage of the closed dump Because the sewage treatment plant is inefficient in removing nutrients and coliforms, it can be inferred that this contamination is associated with the solid waste facility. In the Mutuca River, there were violations of the reference values at all the sampling points, reflecting the negative effects of upstream extensive livestock raising on water quality. The low coefficients of variation for the fecal coliform average suggest that the source of contamination is continuous.

The COD/BOD ratio was very high (above 6.7) for all the rivers, especially for P1 in Elói Mendes and P3 in Santo Antonio do Amparo, reflecting a high level of nonbiodegradable organic matter.

In the Varões River, downstream the solid waste facility, the BOD concentration exceeded the reference value, reaching $6.35 \mathrm{mg} / \mathrm{L}$ (Figure 2). These high values may be associated with the lower river flow for the entire period monitored $\left(0.004 \mathrm{~m}^{3} / \mathrm{s}\right)$ and therefore a lower capacity of dilution of the upstream contaminant load.
The downstream DO in the Mutuca river decreased due to the biological degradation of organic effluents. This interpretation is supported by the lower DO average values $(4.2$ and $3.0 \mathrm{mg} / \mathrm{L})$ found downstream the solid waste facility, which are below the reference value. This finding suggests that there is a source of diffuse pollution upstream the sampling point because no point source of pollution was found on the river and the flows occurring during the period were relatively high $\left(0.386 \mathrm{~m}^{3} / \mathrm{s}\right)$. ADO of $4.4 \mathrm{mg} / \mathrm{L}$ was observed under lower flow $\left(0.283 \mathrm{~m}^{3} / \mathrm{s}\right)$, which may be explained by a lower assimilation capacity by the river.

\section{Water quality index}

Higher WQI values at all sampling points were associated with periods of higher flow rate (Figures 3A, 3B, and 3C). The concentration of pollution indicators was attenuated when there was an increase in flow rate while the pollution load remained constant.

The lowest WQI values occurred at P2 (nearby the downstream point of influx from the Elói Mendes dump) (Figure 3A), being relatively lower in the raining season (October - March) than in the dry season (April - June). This fact is related exclusively to the parameters for turbidity and fecal coliform, which show different averages for the rainy and the dry seasons. Both turbidity and fecal coliform are highly influenced by the rainy season, when increased surface water flow carries loose soil and coliform sources.

The WQI for the Mutuca river was bad $(25<\mathrm{WQI}$ $<50$ ) at all sampling points (Table 4), what may be related to the fact that this river's basin is used for dairy farming.

In the Varões River, the lowest WQI also occurred at P2 (point after the discharge influx point from the sewage treatment plant) (. In the rainy season, the WQI was also lower and increased over the course of the period culminating in the dry season. However, some WQI peaks observed in the dry period, were influenced by an increase in fecal coliform. The average WQI was classified as medium $(50<\mathrm{WQI}<70)$, which is associated to a relatively well preserved area with difficult access (Table 4 and figure 3B).

In the Fabiano river, the worst WQI were found at $\mathrm{P} 1$ and $\mathrm{P} 3$, possible due to cattle raising in the areas that drain in the river (Figure $3 \mathrm{C}$ and table 4 ). The WQI at P3 showed extreme oscillations in the dry season, probably due to the presence of cattle that have free access to the river. The average WQI in the sampling point (66.31) was classified as medium $(50<\mathrm{WQI}<70)$. 

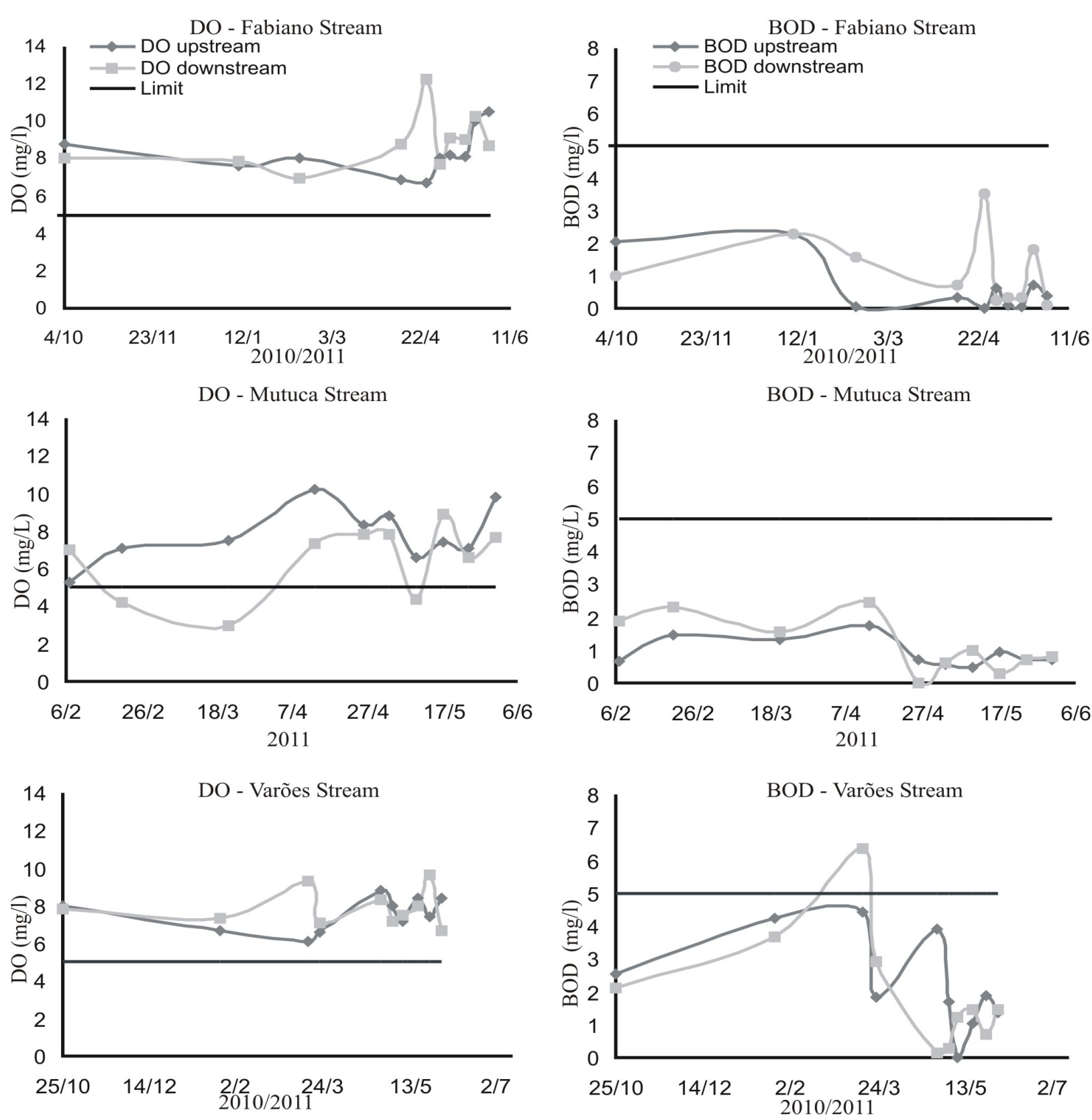

Figure 2 - Concentration of dissolved oxygen and biochemical oxygen demand upstream and downstream the solid waste facility during the study period.

The worst average WQI values were associated with the dump typology of the solid waste facility. However, when the sampling point is considered, Mutuca river (Elói
Mendes city), is classified as having bad WQI at all three sampling points, suggesting that other factors in addition to the dump are contributing to this environmental picture. 


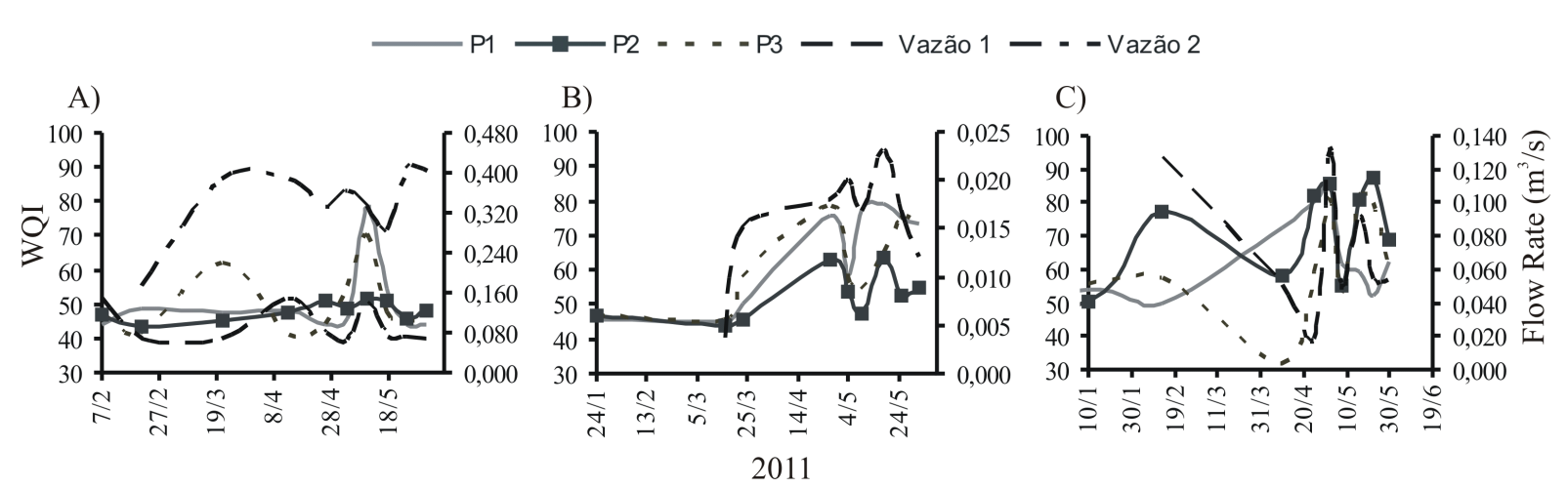

Figure 3 - Temporal and spatial variation of the water quality index related to flow rate for Mutuca (A), Varões (B), and Fabiano $(\mathrm{C})$ rivers.

Table 4 - Average values for the water quality index during the study period and classification according to Igam (2004).

\begin{tabular}{cccc}
\hline Sampling points & Water Quality Index \\
\hline & Mutuca River & Varões River & Fabiano River \\
P1 & 49.94 & 64.45 & 62.56 \\
P2 & 47.95 & 52.37 & 68.96 \\
P3 & 49.99 & 61.57 & 60.68 \\
\hline Average & 49.29 & 59.46 & 66.31 \\
\hline Water Quality Index Classification & Bad & Medium & Medium \\
\hline
\end{tabular}

\section{CONCLUSIONS}

It was not possible to clearly identify significant effects of the solid waste facilities on the water quality indicators likely because of interference from other sources of contaminants. This study identified that water conditions were unsatisfactory due to violations to the allowable levels of phosphorus, ammonia, fecal coliform, and the biochemical oxygen demand/chemical oxygen demand ratio (BOD/COD). Among the three studied rivers, the lowest water quality was observed in the Mutuca river, where the WQI was classified as bad during the entire study period at all three sampling points. The multiple contaminants violations were likely related to other land uses in the drainage area upstream the solid waste facilities. This study suggests that diffuse sources of pollution may be widespread in the region. Further efforts are necessary to comprehensively evaluate sources of pollution in this region and to propose mitigation actions to restore water quality.

\section{ACKNOWLEDGMENTS}

This study was funded by the agreement $\mathrm{n}^{\circ}$ 2091010200509 between the State Environment Foundation
(Fundação Estadual do Meio Ambiente) and the Federal University of Lavras (Universidade Federal de Lavras).

\section{REFERENCES}

AMERICAN PUBLIC HEALTH ASSOCIATION-

APHA, AWWA American Water Works Association, WEF - Water Environmental Federation. FRANSON, M. A. H (Coord.). Standard methods for the examination of water and wastewater. 20 th ed. Washington, D.C.: APHA/AWWA/WEF, 1998. 1134p. ISBN 0-87553-235-7.

AZEVEDO, I. C. A. D. et al. Contaminação do solo e de águas subsuperficiais por metais pesados no antigo lixão de Viçosa, MG, Brasil. Geotecnia, Lisboa, v.26, n.98, p.25-57, 2003.

BRASIL. Ministério do Meio Ambiente (2010). Lei 12305, 02 de agosto de 2010. Institui a Política Nacional de Resíduos Sólidos; altera a Lei no 9.605, de 12 de fevereiro de 1998; e dá outras providências. Diário Oficial da União, Brasília, D.F. 03 de agosto de 2010. 
BRUNNER, C.; BROWN, C. Hospital waste disposal by incineration. JAPCA, London, UK, v.38, n.10, p.12971309, 1988.

\section{CONSELHONACIONALDO MEIOAMBIENTE-} CONAMA. In. BRASIL. Resolução CONAMA n $357 /$ 2005, de 17 de março de 2005. Dispõe sobre a classificação dos corpos de água e diretrizes ambientais para o seu enquadramento, bem como estabelece as condições e padrões de lançamento de efluentes, e dá outras providências. Diário Oficial da União, 18 de março de 2005, p.58-63.

CASTILHO JÚNIOR, A. B (Coord.). Gerenciamento de resíduos sólidos urbanos com ênfase na preservação de corpos d'água: prevenção, geração e tratamento de lixiviados de aterros sanitários. Rio de Janeiro: ABES, 2006.494 p.

CHRISTENSEN, T.H.; KJELDSEN, P. Basic biochemical processes in landfills. In: Sanitary Landfilling: Process, Technology and Environimental Impact. CHRISTENSEN, T.H.; COSSU, R.; STEGMANN, R. (eds.). Academic Press, London, UK, p.29, 1989, Cap. 2.1.

D'ALMEIDA, M. L.; VILHENAA. Lixo Municipal: manual de gerenciamento integrado. 2 ed. São Paulo. IPT/CEMPRE, 2000. 350p. (Publicação IPT 2622)

\section{FUNDAÇÃO ESTADUALDO MEIO AMBIENTE-}

FEAM. Situação do tratamento e/ou disposição final dos resíduos sólidos urbanos - Minas Gerais 2010. Disponível em: http://www.feam.br/images/stories/ minas_sem_lixoes/2011/ mapa_minas_sem_lixao_2010.jpg. Acess em jul. 2011.

HOLT, M. S. Sources of chemical contaminants and routes into the freshwater environment. Food and Chemical Toxicolgy, Orlando, v.38, p.21-27, Apr. 2000. Supplement 1.

\section{INSTITUTOBRASILEIRODE GEOGRAFIAE} ESTATÍSTICA-IBGE. Pesquisa Nacional de Saneamento Básico (2008), Rio de Janeiro, ISBN 978-85240-4135-8, 2010.

INSTITUTO MINEIRO DE GESTÃODAS ÁGUASIGAM. Relatório de monitoramento das águas superficiais na Bacia do Rio Doce. Belo Horizonte, 2004. $231 \mathrm{p}$.
KJELDSEN P. I. et al. Present and long-term composition of MSW landfill leachate: a review. Critical Reviews in Environmental Science and Technology, London, UK, v.32, n.4 p.297-336, 2002.

LANZA, V.C. V. Caderno Técnicode reabilitaçãode áreas degradadas por resíduos sólidos urbanos. Belo Horizonte: Fundação Estadual do Meio Ambiente, 2009. 28 p.

MARKANDYAA. Water quality issues in developing countries. In: LOPEZ R, TOMAN MA, (ed.) Economic Development and Environmental Sustainability. New Policy Options. Oxford University Press, New York, p. 307-344, 2006.

MERTEN, G. H.; MINELLA, J. P. Qualidade da água em baias hidrográficas rurais: um desafio atual para a sobrevivência futura. Agroecologia e Desenvolvimento Rural Sustentável, Porto Alegre, v.3, n.4, p.33-38, out/ $\operatorname{dez} 2002$.

OLIVEIRA, S.; PASQUAL, A. Avaliação da qualidade da água subterrânea a jusante do depósito de resíduos sólidos municipais de Botucatu/SP. Revista Energia na Agricultura, Botucatu, v.16, n.4, p.25-35, 2001.

PEÑIDOMONTEIRO, J.; H. ZVEIBIL, V. Z. (Coord) Manual de gerenciamento integrado de resíduos sólidos. Rio de Janeiro: IBAM, 2001. 200 p.

PESCE, S. F.; WUNDERLIN, D. A. Use of water quality indices to verify the impact of Córdoba City (Argentina) on Suquia river. Water Research, London, UK, v.34, p.2915-2926, (2000).

PINTO, D. B. F. et al. Qualidade da água do Ribeirão Lavrinha na região Alto Rio Grande-MG, Brasil. Ciência e Agrotecnologia, Lavras, v.33, n.4, p.1145-1152, jul/ago. 2009.

POKHRELD.; VIRARAGHAVAN T. Municipal solid waste management in Nepal: practices and challenges. Waste Management, New York, v.25, n.5, p.555-562, 2005.

VON SPERLING, M. Introduçãoà qualidade das águas e ao tratamento de esgotos. Princípios do tratamento biológicos de águas residuárias. Departamento de Engenharia Sanitária e Ambiental. Universidade Federal de Minas Gerais. Belo Horizonte, v.1, 3. Ed, 2005. 452 p. 
WALLS, J. S. Protecting groundwater from landfill leachate. Water Sewage Works, Hamilton, v.122, p. 68, 1975.
ZANONI, A. E. Ground water pollution and sanitary landfills: a critical review. Ground Water, Westerville, v.10, n.3, p.13, 1972.

Ciênc. agrotec., Lavras, v. 36, n. 6, p. 684-692, nov./dez., 2012 